\title{
ESTUDIO SOBRE EL TRATAMIENTO JURÍDICO DEL FACTOR RELIGIOSO EN EL ORDENAMIENTO IRLANDÉS DESDE UNA PERSPECTIVA CONSTITUCIONAL
}

\author{
POR \\ ANA VALERO HEREDIA \\ Universidad de Valencia
}

I. UNA BREVE MIRADA A LA HISTORIA EN BUSCA DE RAZONES

QUE JUSTIFIQUEN LA ENTIDAD DEL FACTOR RELIGIOSO EN EL ORDEN CONSTITUCIONAL DE LA IRLANDA ACTUAL

Los constituyentes de 1937 no se desentendieron del peso de la historia y de los acontecimientos sucedidos hasta y durante la configuración del Estado Libre en el momento de redactar la Norma Suprema de la República de Irlanda. La confluencia en su texto de postulados de signo liberal con otros de claro carácter cristiano-católico refleja el evidente peso que sobre los redactores de la Norma Suprema irlandesa ejercieron dos tendencias filosóficas teóricamente enfrentadas. De un lado, la tradición liberal democrática inherente a la propia configuración del Estado Libre irlandés, y, de otro, por primera vez de manera expresa, la doctrina social de la Iglesia Católica en los ámbitos de la familia, la educación y la 
propiedad privada. Esta confrontación teórica no ha impedido, sin embargo, que durante un extenso período de tiempo ambas concepciones doctrinales -enraizadas en el propio proceso histórico que dio origen al Texto Constitucional- hayan convivido pacíficamente, debido, principalmente, a la extensa aceptación de los postulados católicos por la propia sociedad irlandesa ${ }^{1}$.

Desde 1919, Irlanda ha tenido tres Constituciones escritas. La primera de ellas fue la Constitución de $D$ il iranouya redacción tenía como principal propósito obtener el apoyo internacional en favor de la causa independentista. Así, con el fin de recabar el apoyo del movimiento socialista internacional, el citado texto reflejaba una clara influencia de los postulados del Partido Laborista irlandés. Sin embargo, la vigencia de este documento pronto quedó abatida por el devenir de los acontecimientos. Como es sabido, en 1921, el ala moderada del movimiento independentista concluyó un acuerdo con el Reino Unido por el que el Sur se habría de dotar de su propio gobierno quedando el Norte bajo la dominación del Imperio Británico. Esto condujo a una cruenta guerra civil entre el ala más radical y la fracción más moderada del movimiento independentista, en la que esta última resultó la vencedora. La Constitución del Estado Libre Irlandés de 1922 reflejaba la tradición democrática liberal en la protección de derechos tales como la libertad religiosa, la libertad de expresión y la libertad de asamblea. En 1932, once años después de la independencia, el amplio bloque de republicanos radicales - comprometidos con el sistema constitucional desde 1927-formó gobierno y decidió proceder a la modificación del Texto constitucional de 1922 con el fin de suprimir los nexos que éste todavía establecía con el Imperio Británico, aunque finalmente optaron por reemplazar el antiguo texto por otro completamente nuevo que fue adoptado en referéndum en 1937.

Si bien es cierto que tanto la Constitución de 1922 como la del 37 son fiduciarias de un sustrato ideológico fuertemente reactivo frente a siglos de colonización británica, la Constitución del Estado Libre carecía en su

1 Una de las principales razones por las que históricamente los "unionistas" del Norte se han opuesto a la reunificación de los seis condados del Norte con el resto de la República responde a que aquéllos siempre han mantenido que la "Home Rule», reivindicada por los republicanos del Sur, en realidad implica la concesión de una "Rome Rule». Ello supone que, en caso de que se cediese a la pretensión reunificadora de la República, el código moral católico sería impuesto a la minoría protestante en una Irlanda unificada y mayoritariamente católica. Véase una descripción de la evolución histórica del conflicto en Irlanda del Norte en G.W. HOGAN: "Law and religion: ChurchState Relations in Ireland From the Indepencence to the Present Day", The American Journal of Comparative Noohumen 35, 1987, pp. 47-96. 
texto de referencias expresas a la religión, a excepción de las garantías de la libertad de conciencia y práctica religiosa y la prohibición de discriminación por motivos religiosos ${ }^{2}$. Ello no debe hacer olvidar, sin embargo, que aunque el Texto de 1922 era formalmente neutral, en la práctica el $90 \%$ de la población del nuevo Estado independiente era católica. Este hecho sociológico, unido a una fuerte identificación ideológica entre el movimiento nacionalista y la Iglesia Católica, hizo que la división de la isla en dos entidades políticas reforzase la adopción en el Sur de un sistema de valores confesional como sustrato axiológico del Estado y de sus órganos de actuación ${ }^{3}$. Así, en 1937 se produjo una clara necesidad de reformar la Constitución de la independencia — que había sido ya modificada en veintisiete ocasiones - con el amplio objetivo de adoptar un documento autóctono que reflejase en su texto el sentimiento republicano identificado éste con los postulados de la Iglesia Católica.

Así pues, aprobada en 1937 —en un momento en el que la influencia del clero católico en la vida pública irlandesa se encontraba en su punto álgido-, la Constitución vigente refleja abiertamente dicha influencia en su articulado. La naturaleza de las estrechas relaciones entre la Iglesia y los representantes del Estado independiente fue forjándose a lo largo del siglo $\mathrm{XIX}$, cuando los irlandeses católicos eran una minoría en el seno del Imperio Británico. Como consecuencia de ello, se fue fraguando durante el período de dominación una estrecha vinculación entre el movimiento

\footnotetext{
${ }^{2}$ Hasta 1871 la Iglesia de Irlanda (Anglicana) era la Iglesia establecida por ley. Bajo este sistema, la citada Iglesia estaba legitimada para recibir financiación procedente incluso de aquellos que no pertenecían a la misma y únicamente sus tribunales tenían jurisdicción sobre los asuntos matrimoniales. Antes de 1829 los romano-católicos estaban sujetos a pluralidad de incapacidades legales entre las que se incluía su inhabilitación para ostentar cargos públicos y su Iglesia no recibía financiación pública alguna. Las principales incapacidades legales fueron derogadas por la Roman Catholic Relief Act de 1829, y el establecimiento de la Iglesia de Irlanda fue suprimido por la Irish Church Actde 1869. La jurisdicción matrimonial fue transferida a los tribunales ordinarios a través de la Matrimonial Causes and Marriage Law (Ireland) Ammendment Act de 1870. Para una somera explicación de los antecedentes históricos véase: James CASEY: "Church and State in Ireland", en Church and State In European utiamos Verlagsgesellschaft, Baden-Baden, 1996, pp. 147 y ss.

Desde la supresión en 1871 del establecimiento de la Iglesia de Irlanda, el Estado irlandés no ha convertido en oficial a ninguna religión, ni siquiera a la católica. Parte de la doctrina considera que esto se ha debido exclusivamente al hecho de que la Iglesia Católica nunca ha reclamado su establecimiento.

3Para una exposición detallada del desarrollo de las relaciones entre la Iglesia y el Estado en Irlanda desde la independencia del Estado, véase G. W. HOGAN, Op. cit., pp. 47 y ss; Sheelagh DRUDY and Kathleen LYNCH: Schools and Society in IrGillaard Macmillan Ltd, Dublín, 1993, pp.73 y ss.
} 
nacionalista y la Iglesia Católica que se reforzó con la independencia en 1921.

De forma que el peso de una historia represora de los propios signos de identidad irlandeses justificó la adopción de un Texto estrechamente vinculado con los valores de la doctrina católica e inmensamente benévolo con la propia institución. Si bien la actual Norma Constitucional no establece una religión oficial del Estado, sus antecedentes históricos más cercanos y la clara voluntad de sus redactores de promover la reafirmación identitaria de la República, animaron la redacción de una Norma Constitucional cuyo carácter afín a la religión se anticipa en su propio Preámbulo:

«En nombre de la Santísima Trinidad, de Quien procede toda autoridad y a quien como destino último, deben referirse todas las acciones tanto de los hombres como de los Estados, Nosotros, el pueblo de Irlanda, en reconocimiento humilde de todas nuestras obligaciones con Nuestro Señor Jesucristo, Quien mantuvo a nuestros padres durante siglos de pruebas, en recuerdo agradecido de su heroica e incesante lucha por recobrar la legítima independencia de nuestra Nación, y buscando promover el bien común, con la debida observancia de la prudencia, la justicia y la caridad, a fin de garantizar la dignidad y la libertad del individuo, atender al verdadero orden social, restaurar la unidad de nuestro país y establecer la concordia con otras naciones (...)".

La actual Norma Suprema recoge elementos que ponen en evidencia una clara vinculación entre el Estado irlandés y los principios, dogmas y valores de la Iglesia Católica. De este modo, el propio bienestar del Estado queda claramente subordinado a criterios religiosos en el encabezamiento de la Constitución, y aunque se haya defendido que el Preámbulo no es parte esencial del Texto Constitucional no cabe, sin embargo, infravalorar su significado aunque aquél se encuentre separado de la parte dispositiva de la Norma Fundamental, dado que la propia Corte Suprema ha aludido a él en algunas de sus resoluciones y dado también que los principios establecidos en el Preámbulo se ven reiterados y ratificados en algunos de los preceptos constitucionales ${ }^{4}$. Se hace evidente, por tanto, que modelos de laicidad constitucional como el fran-

${ }^{4}$ Sirva de ejemplo el caso Norris v. Attorney Gen \$1984) IR 36, donde la Corte Suprema estableció: "El Preámbulo de la Constitución orgullosamente afirma la existencia de Dios y de la Más Sagrada Trinidad y dispone que el pueblo de Irlanda reconoce con humildad sus obligaciones para con nuestro Señor Jesucristo. Por lo que no puede ponerse en duda que el pueblo, afirmando y reconociendo sus obligaciones con nuestro Divino Señor Jesucristo, estaba proclamando una profunda convicción religiosa y la intención de adoptar una Constitución coherente con la fe cristiana». 
cés o el americano tuvieron escaso reflejo en la configuración del orden constitucional irlandés, donde el consorcio entre la Iglesia y el Estado se configuró como el signo más certero de una clara voluntad de autoafirmación nacional.

A partir de la independencia del Estado $-\mathrm{y}$ especialmente desde la aprobación de la vigente Norma Constitucional-, la historia del constitucionalismo irlandés se ha caracterizado por dar cobijo a una especie de "confesionalidad católica no declarada» que deriva de la propia redacción original del artículo 44.1 de la Constitución de 1937:

" $2^{\circ}$. El Estado reconoce la especial posición de la Santa Iglesia Católica Apostólica y Romana como guardiana de la Fe profesada por la gran mayoría de los ciudadanos.

$3^{\circ}$. El Estado también reconoce a la Iglesia de Irlanda, la Iglesia Presbiteriana en Irlanda, la Iglesia Metodista en Irlanda, la Sociedad Religiosa de Amigos en Irlanda, así como la Congregación Judía y las demás confesiones religiosas existentes en Irlanda en el momento de entrada en vigor de la presente Constitución».

Durante mucho tiempo el significado de la cláusula de «especial posición" atribuida por la Norma Constitucional a la Iglesia Católica ha sido objeto de debate doctrinal. Las discusiones acerca de la relevancia jurídica de la redacción originaria del artículo 44.1 y de las consecuencias que de ésta podían derivarse no fueron esclarecidas hasta el año 1972 y, mientras tanto, los Tribunales ya habían invocado el precepto en varias de sus sentencias ${ }^{5}$. Mientras parte de la doctrina sostiene que el citado artículo, hoy derogado, otorgaba un privilegio jurídico a la Iglesia Católica respecto de las demás confesiones $-\mathrm{y}$ que, por lo tanto, el credo católico no podía ser tratado en igualdad de condiciones frente al resto de creencias por los poderes públicos_-, la gran mayoría de los autores afirma que la citada previsión únicamente reflejaba y dejaba constancia en la Norma Suprema de una relevancia social sin consecuencia alguna en el terreno

${ }^{5}$ Por todas véase In re Tilson, Infahil951) IR 1. En esta sentencia la Corte Suprema invocó el hoy suprimido artículo $44.1 .2^{\circ}$ junto con el Preámbulo de la Constitución para justificar que "como resultado de la especial posición que la Constitución otorga a la religión católica» la custodia del hijo de un matrimonio fallido entre miembros de la iglesia protestante y católica, debía ser otorgada a la madre por su condición de católica antes que al padre que era protestante. Esto resultaba contrario a la práctica de la época consistente en que, ante la disolución del matrimonio, la custodia de los hijos correspondía al progenitor. 
jurídico-constitucional ${ }^{6}$. La segunda de estas posturas fue la seguida por la Corte Suprema en Quinn?s Supermarket Ldt. V. Attorney General «Esta declaración es un expreso reconocimiento de la coexistencia separada de las distintas confesiones. Dicha previsión no implica una preferencia de una respecto a otras y no confiere ningún privilegio o impone ninguna discriminación o estatus inferior a ninguna confesión religiosa, y no permite al Estado hacerlo».

Poco después del citado pronunciamiento, y debido a la gran controversia que la cláusula suscitaba, el electorado votó en referéndum a favor de la supresión de los párrafos $2^{\circ}$ y $3^{\circ}$ del artículo 44.1. De este modo, la especial referencia a la Iglesia Católica que preveía la Constitución quedó anulada a través de la Quinta Enmienda de la Norma Suprema en $1972^{8}$. No obstante, si se analizan las relaciones entre la Iglesia Católica y el Estado en Irlanda no es osado sostener que -aunque formalmente el Texto de 1937 no establece a la religión católica como la propia del Estado y sitúa a todas las confesiones religiosas en una posición de igualdad — la evolución de la vida pública irlandesa y la configuración de su ordenamiento jurídico reflejan el firme poder del que se ha dotado a aquélla, siendo la educación uno de los ámbitos donde la ostentación de dicho dominio por parte de la jerarquía católica y la lucha por mantenerlo han sido más intensos. Centrando el presente estudio en el orden constitucional establecido por el hoy vigente texto de 1937, puede afirmarse que éste

${ }^{6}$ James CASEY sostiene que esta previsión constitucional es inusual en los textos constitucionales y que es explicable esencialmente en términos históricos y sociológicos. Véase la opinión del autor en Constitutional Law in IrRommed Hall Sweet and Maxwell, Dublín, 2000, p. 686.

7 (1972) I.R. 1.

8 The Fifth Amendment of the Constitutiode A972 (que contiene estos cambios) fue aprobada por 721.300 votos a favor frente a los 133.430 en contra. Véanse tales datos en G.W. HOGAN: "Law and religion...", op.cit., p. 67. Con carácter previo a su efectiva anulación ésta ya había sido recomendada por el "Comité sobre la Constitución" en 1967. Este órgano defendía dicha supresión en los siguientes términos: «Parece no existir duda alguna de que esta provisión ofende a los no-católicos y es además un arma útil en las manos de todos aquellos que ansían enfatizar las diferencias entre el Norte y el Sur (...). Nosotros pensamos, por tanto, que el apartado $2^{\circ}$ debe ser suprimido dado que nuestras circunstancias no requieren ninguna especial mención a una religión particular en la Constitución. Dicha previsión no pretendía otorgar ningún privilegio a la Iglesia Católica y la Iglesia nunca parece haberse situado en una posición privilegiada; sin embargo, la supresión de dicha previsión puede ayudar a dispersar cualquier sospecha a este respecto que persista en la mente de los no-católicos, y eliminar cualquier crítica maliciosa e innecesaria". Véase a este respecto: Report of The Constitution Review 
efectivamente refleja los valores católicos comunes entre la mayoría de la población en el momento de su aprobación, y que muchos de estos elementos - propios de la doctrina social católica- han ido siendo incorporados a la legislación del Estado y han tenido un claro efecto práctico en las sentencias de los tribunales irlandeses ${ }^{9}$.

\section{VALORACIÓN CONSTITUCIONAL DEL HECHO RELIGIOSO.}

El precepto constitucional donde se regula el derecho de libertad religiosa y en el que se establecen las bases sobre las que deben sustentarse las relaciones entre la Iglesia y el Estado en la Constitución de 1937 es el artículo 44:

«El Estado reconoce que se debe homenaje de culto público a Dios Todopoderoso. El Estado reverenciará su nombre, y respetará y honrará la religión.

2. $1^{\circ}$. La libertad de conciencia y a la libre profesión y práctica de la religión, sujetas al orden público y a la moral, están garantizadas a todos los ciudadanos.

$2.2^{\circ}$. El Estado se compromete a no subvencionar ninguna religión.

2.3․ El Estado no puede imponer ninguna limitación ni hacer discriminación alguna por razón de profesión, creencia o estatuto religioso.

$2.4^{\circ}$. La legislación de ayuda estatal a las escuelas no discriminará entre las escuelas dirigidas por diferentes confesiones religiosas, ni deberá crear obstáculos al derecho de cualquier niño a asistir a una escuela subvencionada, sin tener que asistir a la instrucción religiosa en dicha escuela.

$2.5^{\circ}$. Toda confesión religiosa tendrá derecho a administrar sus propios asuntos, poseer, adquirir y administrar bienes muebles e inmuebles y mantener instrucciones con fines religiosos o benéficos.

2.6․ No podrán expropiarse los bienes de ninguna confesión religiosa o institución educativa sino con vistas a obras de utilidad pública, previo pago de indemnización».

9 Tal como se expuso, parte de la doctrina ha sostenido que la «Home Rule» alcanzada primero con la independencia y después con la creación de la República de Irlanda en realidad implica una "Rome Rule», pues el Primer Ministro y padre del texto constitucional vigente, Eamon de Valera, redactó una Constitución que refleja en muchos de sus artículos la doctrina de la Iglesia Católica. Este tipo de afirmaciones han sido puestas de manifiesto por Noel BROWNE: "Church and State in Modern Ireland" en VV.AA, Ireland?s Envolving Constitution, 1937-97: CollectHatsaubdishing, Oxford, 1998, pp. 41-50 y en esta misma obra colectiva por Desmond M. CLARKE: "Education, the State and Sectarian Schools", pp 65-79. 
De la lectura del presente artículo puede deducirse, en primer lugar, que en el ámbito del derecho fundamental de libertad religiosa queda efectivamente protegida la libertad de cada individuo para autodeterminarse en el terreno espiritual y para ejercer su opción religiosa con plenas garantías y sin experimentar por ello discriminación alguna frente a quienes hayan optado por cualquier otra opción, sea ésta fideísta o no, mayoritaria o minoritaria. La libertad religiosa individual es un derecho ya presente en la tradición jurídica del nuevo Estado irlandés incluso con anterioridad a la redacción de las Cartas Constitucionales del 22 y del 37. Así, el propio Tratado Anglo-Irlandés de 6 de diciembre de 1921, que establecía las bases para la proclamación de un Estado independiente irlandés, ya fijaba en su artículo 7 el reconocimiento y garantía del derecho de libertad religiosa, y éste fue más tarde introducido a través de su artículo 8, en la Constitución del Estado Libre Irlandés de 1922, que preveía:

"La libertad de conciencia y la libre profesión y práctica de la religión está sujeta al orden público y a la moralidad, garantizada a todos los ciudadanos, y ninguna ley debe de hacerse para financiar directa o indirectamente ninguna religión, o para prohibir o restringir su libre ejercicio o dar alguna preferencia, o imponer alguna discriminación por razón de creencias o status religioso, o que afecte perjudicialmente al derecho de cada niño de asistir a la escuela recibiendo dinero público sin recibir instrucción religiosa en la escuela, o hacer alguna discriminación en el ámbito de las ayudas del Estado entre escuelas que se encuentren bajo la gestión de las diferentes confesiones religiosas $(\ldots)$ ".

Se observa, por tanto, que el precedente de la vigente Constitución ya proclamaba el reconocimiento de una libertad cuya efectividad práctica ha sido dudosa en el desarrollo del propio orden constitucional vigente. En este sentido, es importante dejar apuntado de antemano que la salvaguarda de la libertad religiosa y la exacta definición de las relaciones entre la Iglesia y el Estado no ha sido una cuestión especialmente polémica en Irlanda hasta épocas recientes, a diferencia de lo sucedido en otros países de tradición constitucional continental como España, Italia o Alemania. En Irlanda, en discrepancia con lo acaecido incluso en EEUU país de tradición jurídica más afín a la irlandesa-, las relaciones entre la Iglesia y el Estado han sido, y siguen siendo, una cuestión que no ha planteado especiales controversias, hecho que resulta ajeno a otras realidades constitucionales como la española, alemana o americana, donde la definición del derecho de libertad religiosa o la delimitación del papel del Estado frente al fenómeno religioso, ha sido, sin duda, una de las cuestiones más conflictivas y que más dificultades jurídicas ha sugerido. $Y$ es que en Irlanda - debido principalmente al alto grado de aceptación social de la doctrina católica- raramente han Ilegado a los Tribunales 
supuestos en los que se haya cuestionado la implicación del Estado en los asuntos religiosos o la excesiva influencia de la doctrina y moral católicas en la política y en la vida públicas, realidad que ha venido generando una cierta homogeneidad social difícilmente compatible con el cuestionamiento en sede judicial de prácticas que en muchas ocasiones ponen en entredicho la neutralidad estatal frente al fenómeno religioso ${ }^{10}$.

A diferencia de lo que ocurre en Italia o España, las relaciones entre la Iglesia y el Estado no están reguladas en Irlanda por concordato y el artículo 44 de la Constitución no establece un deber del Estado de cooperar con las confesiones religiosas, tal y como se encuentra previsto en el párrafo 3 del artículo 16 de la Constitución española ${ }^{11}$. Sin embargo, tampoco es constitucionalmente admisible que el Estado pueda permanecer insensible ante el fenómeno religioso, dada la expresa alusión al carácter religioso del pueblo irlandés que en ella se contiene y dado que, a tenor del párrafo $2.4^{\circ}$ del citado artículo 44, los poderes públicos han de tomar en consideración las creencias religiosas de la sociedad, con el fin de permitir la articulación de un sistema educativo acorde con ellas.

De todo lo expuesto se deduce que, en la redacción del artículo 44, los constituyentes irlandeses se decantaron por la configuración de una fórmula ambigua, en la que el respeto a la libertad religiosa de los individuos se quiso armonizar con la constatación del carácter primordialmente religioso de su sociedad, del que las instituciones del Estado no deben ser desconocedoras.

\section{SOBRE EL CONCEPTO DE LIBERTAD RELIGIOSA EN LA NORMA FUNDAMENTAL IRLANDESA.}

Como ha quedado expuesto con anterioridad, puede afirmarse que los principios rectores que sustentan la definición del derecho de libertad religiosa en la Constitución irlandesa quedan establecidos en su artículo 44. Al análisis detallado de las facultades que otorga esta libertad, sus condiciones de ejercicio y los límites que le son constitucionalmente aplicables será dedicado este epígrafe.

10 Véase un examen pormenorizado del alto grado de influencia de la doctrina y moral católicas en la política pública en J.H. WHYTE: Church and State in Modern Ireland: 1923-197Gill and Macmillan, Dublín, 1980 y AAVV: Religion, Morality and Public Pol,iDominican Publications, Dublín, 1995.

11 Véase al respecto J.H. WHITE: op. cit., p. 15. El autor afirma que: «Ningún concordato entre la Iglesia y el Estado ha sido nunca negociado ya que nunca ha sido sugerido por ninguna de ambas partes". 
Como se desprende de la lectura de sus distintos párrafos, el precepto constitucional no se limita a garantizar la libre profesión y práctica de la religión sino que, asimismo, establece la prohibición de su subvención o financiación pública; instituye el principio de no discriminación por razón de profesión, creencia o estatuto religioso; e instaura el principio de neutralidad de los poderes públicos en su política de ayuda estatal a las escuelas dirigidas por diferentes confesiones religiosas, no debiendo el Estado crear obstáculos al derecho de cualquier niño a asistir a una escuela subvencionada, sin tener que asistir a la instrucción religiosa en dicha escuela. Finalmente, la autonomía de las distintas confesiones religiosas queda garantizada al preverse que toda confesión religiosa tendrá derecho a administrar sus propios asuntos, y se garantiza, igualmente, la inmunidad de sus propiedades salvo en el caso excepcional de que su afectación sea necesaria por motivos de utilidad pública, previo pago de la correspondiente indemnización económica.

\section{Libertad de conciencia y libertad de profesión y práctica religiosa.}

El primer apartado del artículo 44.2 protege la dimensión subjetiva del derecho de libertad religiosa, que debe concretarse, de un lado, en aquella autodeterminación religiosa garantizada por la inmunidad de coacción frente a los poderes públicos; y de otro, en la facultad de adoptar una determinada creencia religiosa, así como de rehusarla o abandonarla. Además, la autonomía moral de la persona comporta la eventual y consecuente exteriorización de tales creencias religiosas, con el único límite constitucional que deriva de la previsión de una cláusula de orden público especialmente controvertida, en cuanto que alude, además, y como límite expreso frente a la libertad religiosa, a la moral. La determinación de a qué tipo de moral se subordina el ejercicio del derecho es una cuestión singularmente delicada en un ordenamiento jurídico donde la ley natural inspira multitud de resoluciones judiciales, de forma que la precisión del carácter amplio o restrictivo del límite vendrá a configurar el grado de laxitud del propio derecho ${ }^{12}$.

12 La ley natural fue citada por la Corte Suprema en el caso MCGeev V. Attorney General(1974) I.R. 284, donde dispuso: "Los individuos son titulares de derechos naturales y humanos por encima de los cuales el Estado no dispone de autoridad alguna; y la familia como unidad natural, primaria y fundamental de la sociedad, tiene derechos sobre los que el Estado no ejerce ningún control». Asimismo, la naturaleza cristiana y democrática del Estado ha sido citada judicialmente en varias ocasiones. Sirvan de ejemplo los casos Ryan V. Attorney Gene(1965) I.R. 294; The State (K.M) V. Minister 
La redacción del párrafo primero del artículo 44.2 es idéntica a lo previsto por el artículo 8 de la Constitución irlandesa de 1922. El significado de dicha disposición sólo ha sido abordado constitucionalmente en una ocasión, en la que se adoptó una interpretación "restringida" y "restrictiva" de la libertad de conciencia. En McGee v. Attorney Genełż,la Corte Suprema dispuso que "la libertad de conciencia sólo debe ser entendida como la libertad de elegir una determinada religión y de actuar en concordancia con sus preceptos; igualmente, este derecho ampara la libertad de no adoptar ninguna creencia religiosa o de abstenerse de practicar o profesar ninguna religión". De modo que, de conformidad con dicha interpretación, la libertad de conciencia prevista en el citado artículo, en su dimensión positiva o negativa, sólo será constitucionalmente amparable en el ámbito religioso. Sin embargo, parece improbable a este respecto la continuidad de pronunciamientos tan limitados en el futuro ya que, tal y como ha puesto de manifiesto la doctrina, dicha cláusula constitucional debe ser interpretada de manera que integre como ámbito de su protección creencias morales o éticas del individuo que no necesariamente queden circunscritas a un concepto tradicional de religión ${ }^{14}$.

En paralelo con esta cuestión hay que tener en cuenta otra no menos importante, cual es el deber de neutralidad que frente al fenómeno religioso impone al Estado la dimensión objetiva de las libertades fundamentales reconocidas en el artículo 44.2.1 ${ }^{\circ}$. Ésta demanda de los poderes públicos una conducta y actitud de neutralidad ideológica y religiosa atendible sólo si sus

for Foreign Affa(i1999) I.R. 73 y Kennedy V. Irelati687) I.R. 587, donde la High Court hizo referencia a la naturaleza cristiana y democrática del Estado como fuente u origen de pluralidad de derechos personales. Michael FARRY señala que la identificación entre los derechos constitucionales y la ley natural o la naturaleza cristiana y democrática del Estado es problemática, pues considerar a la ley natural como fuente de derechos personales implica un alto grado de inseguridad e incerteza jurídica en cuanto al contenido de estos últimos. Igualmente, sostiene el autor que la identificación entre los derechos constitucionales y la naturaleza cristiana del Estado deriva en una exclusión de todos aquellos credos distintos al cristiano. Véase su opinión en: Education and the ConstitutipRound Hall Sweet and Mazwell, Dublin, 1996, pp. 1-6. Igualmente véase al respecto William DUNCAN: "Can Natural Law be used in constitutional interpretation?", Religion, Morality and Publicopociti, qp. 125-129.

13 (1974) IR 284; (1975) ILTR.

${ }^{14} \mathrm{EI}$ "Constitution Review Group» sostiene a este respecto que deben considerarse integradas en el ámbito de protección de "la libertad de conciencia» aquellas convicciones que formen parte de otros sistemas morales, tales como los valores filosóficos o 
órganos renuncian a toda forma de adoctrinamiento. La defensa de un punto de vista como el expuesto exigirá, en epígrafes posteriores, abordar la actitud del Estado en el ámbito educativo, con el fin de comprobar si efectivamente cumple con los deberes derivados del propio mandato constitucional.

\section{Prohibición constitucional de la financiación estatal de la religión.}

El artículo 44 de la Constitución irlandesa no contiene una cláusula equivalente a la "Cláusula de Establecimiento" americana en la que se instaura expresamente un wall of separaténtre el Estado y la religión. La teoría de separación, definida por primera vez por la Corte Suprema Americana en Everson $v$. Board of Educatisumpone que los poderes públicos no pueden interferir en las creencias ni en las prácticas religiosas de los ciudadanos, ni pueden fomentar o promover por medio alguno la religión ni establecer una confesión como oficial; asimismo queda vedada la posibilidad de dispensar un trato más favorable a una determinada confesión religiosa y, desde luego, adoptar leyes que supongan la financiación o subvención directa o indirecta de una religión concreta ${ }^{15}$. Como es bien sabido, sin embargo, la interpretación de la disposición americana, que incluye asimismo la cláusula de libre ejercicio y su articulación con las cláusulas de neutralidad e igualdad, ha diferido a lo largo de la historia de la jurisprudencia del Tribunal Supremo.

Así, si bien la Norma Suprema estadounidense dispone a partir de su Primera Enmienda que «El Congreso no elaborará ninguna ley referente al establecimiento de la religión o que prohíba su libre ejercicio", la Constitución irlandesa se limita a prevenir la subvención económica por parte del Estado de cualquier confesión religiosa, así como a impedir la discriminación por motivos religiosos. De forma que, en principio, en el Estado irlandés no hay una limitación de la acción del Estado similar en materia religiosa, al no existir la misma barrera entre el Estado y la religión que en el orden constitucional americano. Esto ha inducido a parte de la doctrina a afirmar que la prohibición contenida en el artículo $44.2 .2^{\circ}$ de la Constitución irlandesa no impide el establecimiento de una religión como propia del Estado ${ }^{16}$. Sin embargo, si se atiende a una interpretación siste-

15330 U. S 1 (1947).

${ }^{16}$ En este sentido, James CASEY sostiene que la Constitución irlandesa no prohíbe el establecimiento de una religión; lo único que proscribe la Carta Magna es que se concedieran privilegios legales a una Iglesia establecida frente a otras. Véase la opinión del autor en "State and Church in Ireland», op. cit., pp. 151 y ss. 
mática de la Constitución, la armonización del párrafo $2.2^{\circ}$ del artículo 44 con el resto de preceptos constitucionales contrarresta su propio alcance. Y ello porque no cabe desconocer que la prohibición que recae sobre el Estado de imponer discriminación alguna en el ámbito religioso, promulgada en el párrafo $2.3^{\circ}$ del mismo artículo 44 , implica que todas las confesiones religiosas quedan agrupadas bajo un mismo principio de trato igualitario, en cualquier caso incompatible con el establecimiento de una confesión religiosa como propia del Estado. En concordancia con ello, parte de la doctrina defiende que Irlanda no tiene una religión establecida - no es un Estado confesional-y que, además, cualquier intento de adopción de una iglesia como propia del Estado sería inconstitucional en virtud de la exclusión en la Norma Suprema de toda forma de discriminación religiosa. De manera que, "la combinación de las cláusulas de no discriminación y de no financiación contenidas en la Norma Suprema irlandesa, constituyen el aproximado equivalente a la Cláusula de Establecimiento americana» ${ }^{17}$.

Además, recientemente la Corte Suprema irlandesa ha confirmado en su jurisprudencia que el marco previsto por la Constitución impide el establecimiento de una confesión religiosa como propia del Estado. A este respecto, en el caso Campaign to Separate Church and State V. Minister for Educatizor la Alta instancia irlandesa ha dispuesto que el artículo 44 prohíbe implícitamente el establecimiento de una religión, al sostener que: "A pesar de que no existe una previsión constitucional que prohíba el establecimiento (...) de una iglesia por ley, resulta obvio que una ley de ese tipo sería imposible de conciliar con la prohibición de discriminación religiosa contenida en el artículo $44 \cdot 2 \cdot 3^{\circ}$ ".

Una vez despejadas las incógnitas acerca de la imposibilidad teórica de establecer una iglesia nacional en Irlanda, conviene abordar el estudio de la proscripción de financiación estatal de la religión expresamente impuesta por el párrafo $2^{\circ}$ del artículo 44.2 de la Constitución. Ésta ha sido

${ }^{17}$ Gerard WHYTE afirma que cualquier tentativa de establecer una religión como propia del Estado resultaría del todo inconstitucional, pues chocaría con la cláusula de no discriminación prevista en el propio artículo 44. Véase la opinión del autor en "Religion and the Irish Constitution», John Marshall Law Revi øú́m. 3, Volumen 30, 1997, p. 731. En sentido contrario, James CASEY considera que no existe una prohibición clara en la Constitución en cuanto al establecimiento de una religión, aunque el propio autor reconoce que una interpretación sistemática del artículo 44, que tome en consideración las distintas previsiones que en él se contienen, impide que legalmente se pueda establecer una religión como propia del Estado, en el sentido de reconocer una Iglesia nacional. Para una exposición de las consideraciones del autor consúltese Constitutional Law in I røpaoit., p. 686 y "State and Church in Ireland», op. cit., p. 151. 
examinada judicialmente tan sólo en dos ocasiones. En un primer momento, la Corte Suprema hizo alusión a dicho precepto en el caso McGrath and

Ruairc v. Trustees of Maynooth C8IEgeste supuesto los demandantes planteaban la inconstitucionalidad de la financiación pública del Colegio Maynooth, que por ley es un seminario pero que funciona, al mismo tiempo, como Universidad Pontificia y como reconocido colegio de la Universidad Nacional de Irlanda. La Suprema Corte afirmó que, en función de este último carácter, la financiación estatal recibida por el citado Colegio no era constitucionalmente objetable. La segunda de las ocasiones en que se ha planteado la constitucionalidad de subvenciones otorgadas por el Estado a entidades de carácter religioso ha sido en el reciente y ya citado caso Campaign to Separate Church and State V. Minister for Educational hilo de una de las tantas cuestiones que en materia educativa ponen en entredicho el principio de neutralidad religiosa del Estado, y que, por lo tanto, será abordada con más detenimiento en próximos epígrafes. Quede constancia ahora de que en esta ocasión la Corte Suprema clarificó el significado de la expresión "financiación de una religión" al determinar que: «El artículo $44.2 .2^{\circ}$ en realidad hace inconstitucional la cesión de propiedades o la atribución de ingresos a una religión de manera perpetua o cuasiperpetua». En este caso, el Alto Intérprete de la Constitución cerró las puertas a cualquier sistema de financiación igualitario entre las distintas confesiones religiosas al rechazar la constitucionalidad de cualquier tipo de financiación concurrente - es decir, aquella en la que los beneficios financieros pudiesen ser conferidos a todas las religiones por igual一.

La letra de este artículo impone al Estado una prohibición absoluta en cuanto a la financiación de la religión salvo en materia educativa, como se verá en páginas posteriores. En principio, una interpretación estricta de este precepto implica que en Irlanda no cabe un sistema de financiación mediante la declaración de la renta, en los términos del modelo español o alemán, porque incluso la utilización de la maquinaria del Estado para llevar a cabo la citada recaudación podría ser entendida como una financiación indirecta de la religión. Sin embargo, esta prohibición constitucional no ha impedido que sean distintos los ámbitos en los que se produce una efectiva financiación indirecta de las actividades desarrolladas por las confesiones religiosas. A este respecto, debe atenderse a continuación a dos cuestiones relevantes: de un lado, la admisibilidad constitucional de las ayudas estatales

19 (1979) ILRM 166. 
dirigidas a entes religiosos que tengan propósitos estrictamente seculares; y de otro, la aceptabilidad de dicha financiación cuando la cláusula de libre ejercicio y la efectividad del propio derecho así lo requieren.

Por lo que a la primera cuestión se refiere, es importante poner de manifiesto que varios son los frentes en los que la ayuda económica estatal es depositada en manos confesionales para propósitos distintos a los religiosos en Irlanda, siendo la confesión católica la casi exclusiva receptora de tal asistencia. Al respecto, en el ámbito sanitario, la mayor parte de los hospitales irlandeses están dirigidos, administrados y gestionados por órdenes católicas. En términos de principio, en su labor de suministrar fondos públicos para la financiación de los equipos médicos y los salarios del personal de los citados hospitales - que están abiertos a todos- el Estado no estaría actuando en contra de la previsión constitucional del artículo $44.22^{\circ}$, ya que la finalidad de las dotaciones económicas no es religiosa ${ }^{20}$. Sin embargo, resulta fehaciente que en los hospitales que pertenecen a una orden religiosa y que reciben financiación pública, a pesar de que no pueden restringir el acceso de pacientes, hay cierto tipo de tratamientos legales pero no aceptados por la Iglesia Católica- que no pueden ser dispensados. En este sentido $-\mathrm{y}$ aunque al amparo de lo previsto por el artículo $44.2 .5^{\circ}$ no puede ser cuestionado el derecho de la lglesia a poseer y dirigir hospitales o centros médicos-, resulta necesario cuestionarse la constitucionalidad de dichas subvenciones estatales destinadas a financiar instituciones que rechazan la práctica de determinados tratamientos sanitarios, teniendo en cuenta que éstos sí que pueden ser dispensados, sin

20 Para el tema de los hospitales y su financiación véase Brendan HENSEY: The Health Services of Ir Dublín, 1979, pp. 137-139 y James CASEY: "State and Church in Ireland", State and Church in European Unoiporcit., pp. 155 y ss.

21 James CASEY sostiene que es más que discutible la constitucionalidad de las ayudas estatales a los hospitales dirigidos por órdenes religiosas sobre la base del artículo 44.2.2 $2^{\circ}$. Véase la opinión del autor en Constitutional Law in Irepaciła, pp. 696 y 697. Asimismo, el "Constitutional Review Group" ha señalado la dudosa constitucionalidad de la financiación pública de instituciones del área de la salud pública que pertenecen a una orden católica. En relación con esto, el citado Grupo pone un ejemplo muy ilustrativo al señalar que sólo basta imaginar que en un área determinada el único hospital que existiese fuera uno perteneciente a la Iglesia Católica pero financiado públicamente. Imaginando que el comité ético de dicho hospital decidiera que en el mismo no serán dispensados tratamientos de esterilización, los pacientes de dicha área tendrían que recorrer una larga distancia para dirigirse a otro hospital que les proporcionase el citado tratamiento. Por lo cual, el "Constitutional Review Group» cuestiona la constitucionalidad de actuaciones consistentes en el rechazo a la práctica de ciertos tratamientos legales por parte de los hospitales financiados con fondos públicos. Véase 
embargo, en el resto de hospitales públicos ${ }^{21}$.

Asimismo, una interpretación restrictiva del principio de no financiación ha conducido a la Corte Suprema y a la mayor parte de la doctrina a admitir la constitucionalidad del pago de los salarios de los profesores de religión e incluso de los capellanes que desempeñan su labor en las escuelas confesionales católicas de secundaria. Sin perjuicio de que se pase de puntillas sobre este tema, ya que constituirá uno de los pilares de próximas reflexiones, cabe resaltar, ya de antemano, que la legitimidad de la financiación estatal del sistema educativo en general —cuyo carácter confesional es indiscutible-, así como el carácter público de las retribuciones de profesores y ministros de la confesión católica en las aulas irlandesas, descansa, según lo dispuesto por la jurisprudencia constitucional, sobre la base de los fines educativos a los que estas ayudas se dirigen.

Parece, por tanto, que se ha producido una evolución en términos de hermenéutica constitucional en los pronunciamientos de la Corte Suprema relativos al significado y alcance del artículo 44 de la Constitución. Así, se ha pasado de una interpretación sistemática del precepto en la cuestión relativa a la imposibilidad de establecer por ley una iglesia nacional en Irlanda, ya que dicho establecimiento entraría en contradicción con el principio de no discriminación religiosa recogido en el mismo artículo, a la utilización, por la Corte Suprema, de un criterio de interpretación teleológica sobre la base del cual puede extraerse del precepto que los fines sanitarios o educativos a los que se destinan las dotaciones económicas estatales justifican el incumplimiento de la literalidad constitucional que prohíbe expresamente la financiación pública de la religión.

La segunda de las materias a las que se hizo alusión líneas atrás es la relativa a la constitucionalidad de las ayudas financieras recibidas por entes religiosos, cuando dichas ayudas son necesarias para garantizar la efectividad de la libertad religiosa en su vertiente subjetiva. La plenitud del derecho de libertad religiosa y la libre profesión y práctica de la religión justifican la adopción por parte del Estado de medidas, incluso financieras, tendentes a garantizar la efectividad del ejercicio del derecho a personas que se encuentran en una relación de sujeción especial con el Estado como es el caso de los internos en los centros penitenciarios, los miembros de las Fuerzas Armadas o las personas residentes en hospitales ${ }^{22}$. El derecho a la asistencia religiosa en los establecimientos públicos se configura, pues, como una de las facultades esenciales de la libertad religiosa, en la medida

22 Esta situación es la prevista por el artículo 39 de The Health Ade 1970 que obliga a las instituciones sanitarias a adoptar las correspondientes medidas para hacer efectiva la previsión de servicios religiosos en cada hospital o sanatorio. 
en que la garantía de su plena efectividad para determinados colectivos justifica que el Estado sufrague los salarios de los ministros de las distintas confesiones religiosas que prestan sus servicios en dichos establecimientos. La prohibición contenida en el artículo $44.2 .2^{\circ}$ queda neutralizada en este caso por la obligación incluida en el párrafo $1^{\circ}$ del mismo artículo, ya que la garantía de la libre práctica de la religión se configura como el objetivo prioritario del artículo 44 de la Carta Magna irlandesa.

\section{Prohibición de discriminación por motivos religiosos.}

De acuerdo con lo mantenido hasta el momento, puede extraerse que de la valoración positiva que del hecho religioso hace la Constitución irlandesa, se deriva la obligación de los poderes públicos de garantizar la efectividad y el pleno ejercicio del derecho de libertad religiosa de los ciudadanos, mediante la eliminación de todos los obstáculos que lo dificulten y la adopción de todas las medidas que garanticen la igualdad de condiciones en su disfrute.

Al igual que en Estados Unidos, en Irlanda se han planteado conflictos en torno a la aplicación de la que podría denominarse cláusula de libre ejercicio o práctica religiosa -prevista en el artículo $44.2 .1^{\circ}$ de la Constitución irlandesa - frente a la cláusula de no discriminación —contemplada en el artículo $44.2 .3^{\circ}$ de la Norma Suprema-. La Sentencia más importante en esta materia es la dictada por la Corte Suprema en el caso

Quinn?s Supermarket Ltd. V. Attorney ${ }^{2}$ GeEneste supuesto la Corte declaró expresamente que el Estado no puede adoptar distinción alguna basada en la profesión, creencia o estatus religioso de los ciudadanos, pues cualquier singularidad en este ámbito sería constitutiva de discriminación. La imparcialidad del Estado en esta materia veda incluso cualquier trato no igualitario entre creyentes y no creyentes según lo dispuesto por la Alta instancia irlandesa en el caso Mulloy $v$. Minister for Edútatiéon esta manera, la Corte Suprema se decantó por un concepto amplio y no exclusivamente teísta de libertad religiosa, en consonancia con lo mante-

23(1972) I.R.1.

24 (1975) IR 88.

${ }^{25}$ Como es sabido, en EEUU, a partir de los años sesenta, empezó a adoptarse un concepto amplio de religión que incorporaba las opciones no teístas. El primero de los casos fue Torcaso v. Watkien 1961, 367 US 488 (1961), donde el Tribunal Supremo afirmó que "el Estado no puede imponer ninguna exigencia que ayude a todas las religiones frente a los no creyentes, ni tampoco puede ayudar a aquellas religiones basadas en la creencia en un solo Dios frente a religiones que tienen diferentes creencias". 
nido por el Tribunal Supremo de los Estados Unidos ${ }^{25}$. La relevancia y el alcance de tal aseveración es amplísima, en la medida en que viene a considerar englobadas en el ámbito de protección de la libertad religiosa tanto las convicciones de quienes mantienen un credo de carácter confesional como las de los que defienden una postura agnóstica frente al hecho religioso. Es más, dicha previsión de la Corte Suprema viene a proscribir cualquier distinción basada en las opciones espirituales de los individuos.

Pero la trascendencia de la citada sentencia alcanza cuotas superiores si se tiene en cuenta que en ella la Corte Suprema reconoció, asimismo, que no toda norma estatal que establezca una distinción entre ciudadanos es constitucionalmente inválida, sino que será admisible toda aqueIla disposición distintiva que tuviere como finalidad asegurar la libre práctica y el ejercicio de la religión. Dicho con otras palabras, la discriminación religiosa por parte del Estado no es inválida cuando la implementación de la garantía de la libre profesión y práctica de la religión requiera el otorgamiento de un tratamiento diferenciado a los miembros de una determinada confesión religiosa. La principal finalidad del artículo 44 es garantizar la libre práctica y el ejercicio independiente de la religión, de modo que cualquier ley que en su aplicación produjere un efecto restrictivo sobre dicho fin, con respecto a una persona o colectivo, será constitucionalmente inválida. Se observa cómo el Alto Tribunal recurre nuevamente a una interpretación teleológica del precepto constitucional, pero en un sentido distinto a como lo hizo en materia de financiación de la sanidad o la educación. Si en aquella ocasión la Corte utilizó el criterio de interpretación teleológica para superar así una interpretación sistemática del artículo 44, en este caso, dicho criterio hermenéutico le es de utilidad para convertir en constitucional una aparente discriminación en el ejercicio de la libertad religiosa.

A este respecto, la doctrina de la Corte Suprema irlandesa es claramente receptora de la jurisprudencia del Alto Tribunal americano ${ }^{26}$. Como es sabido en EEUU el "principio de acomodación» o "teoría de las acomodaciones permisibles" ha permitido relativizar - a través de los pronunciamientos del Tribunal Supremo americano- las estrictas normas de separación entre la religión y el Estado derivadas de la Cláusula de Establecimiento y de su interpretación por la primera jurisprudencia norteamericana. Dicha acomodación se origina cuando el Gobierno pretende

26 Esta decisión estuvo claramente influida por la jurisprudencia del Tribunal Supremo de EE UU: MCGowan v. Marylan\$66 US 420 (1961); Sherbert V. Vern374 US 398 (1963); Braunfeld v. Brow366 US 599 (1961); Abington School District v. 
promover los valores recogidos por la Cláusula de Libre Ejercicio eximiendo a individuos con creencias religiosas del cumplimiento de determinadas normas estatales. La acomodación tiene su finalidad o razón de ser en la protección del libre ejercicio de la religión ${ }^{27}$. La Corte Suprema irlandesa ha sostenido que el principal objetivo del artículo 44 es garantizar la completa libertad de la práctica religiosa ${ }^{28}$. En este sentido, cualquier distinción creada por ley que tenga como objetivo garantizar la plena efectividad de la libre profesión, creencia o estatus religioso tendrá cabida constitucional. De forma que, cuando la libre práctica o profesión de la religión necesite de una excepción respecto a la aplicación de las previsiones de un estatuto general, dicha excepción puede ser válidamente otorgada ${ }^{29}$.

Quinn?s Supermarket Ltd. V. Attorneffueseguidb, en 1974-75

${ }^{27}$ El caso en el que la doctrina de la acomodación alcanzó su cima fue Corporation of Presiding Bishop $v$. :A483 US 327 (1987). En él se señaló que no era contraria a la cláusula de establecimiento la ley que permitía que las normas sobre discriminación en el empleo no fueran aplicadas a las corporaciones religiosas en el momento de contratar a personal, siempre que se contratase a una persona de esa religión y para realizar tareas directamente relacionadas con las actividades de la misma.

28 Quinn?s Supermarket Ltd. V. Attorney G\$7972aly Mulloy v. Minister for Education(1975)

${ }^{29}$ Quinn?s Supermarket Ltd. V. Attorney (1972tal

30 (1975) IR 88. En este caso se planteaba la constitucionalidad de una norma ministerial de 1958 que preveía el pago de un incremento salarial a los profesores de Secundaria que hubiesen desempeñado servicios en ciertos países en vías de desarroIlo; sin embargo, la concesión de dicho crédito estaba restringida a los profesores laicos. Al demandante - sacerdote que había prestado los servicios previstos por la norma ministerial- le fue rechazada la concesión de dicho crédito por el Departamento de Educación ante lo cual reclamó la inconstitucionalidad de la citada norma. La High Court y la Corte Suprema unánimemente le dieron la razón. En la Corte Suprema, el Juez Walsh, haciendo alusión al principio proclamado en Quinn?s Supermarkedispuso que si dicha discriminación fuese admitida sería tanto como aceptar que el Estado puede preferir a personas religiosas sobre las laicas o viceversa para materias que en modo alguno tienen que ver con la salvaguarda o mantenimiento del derecho constitucional a la libre práctica de la religión, no estando legitimado el poder público para hacer algo semejante. Y que, además, en el caso concreto, dicha distinción basada en el estatus de la persona no podía ser interpretada como necesaria para implementar el derecho constitucional a la libre práctica de la religión, lo que implica que el Estado no puede imponer limitación alguna o discriminación entre personas pertenecientes a una confesión religiosa o entre ellas y las que no pertenecen a ninguna, salvo que fuese necesario para asegurar la garantía de la libertad religiosa y de conciencia. En esta Sentencia, la Corte Suprema aclaró el significado de la expresión "profesión, creencia o estatus religioso" haciendo referencia, las dos primeras, a la fe particular profesada por un individuo, y el estatus a la posición o rango de una persona dentro de una determinada confesión religiosa o creencia, incluyéndose a los no creyentes. 
por otros dos casos en los que el concepto de discriminación religiosa fue estudiado en mayor profundidad: el ya citado Mulloy v. Minister for Eąqation

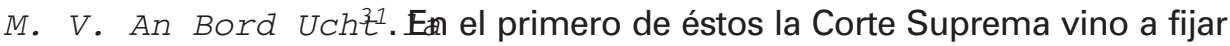
que la constitucionalidad de toda norma estatal que estableciese una distinción de orden religioso quedaba subordinada a su estricta necesidad para garantizar el libre ejercicio de la religión. Lo que significa que sólo será constitucionalmente admisible una norma que establezca alguna discriminación por razón de la profesión, estatus o creencia religiosa, cuando ésta vaya destinada a implementar o permitir el ejercicio del derecho a la libre práctica de la religión y sea estrictamente necesaria para ello. Sin embargo, el Alto Tribunal irlandés -a diferencia del Tribunal Supremo norteamericano- no estableció los criterios para determinar qué tipo de normas quedarían excluidas de tal principio de necesidad. Como es sabido, la Corte Suprema americana instauró una serie de principios para precisar cuándo una norma puede devenir inconstitucional por vulnerar el libre ejercicio de la libertad religiosa en el denominado compel Iing interest stan $3 z_{a}$ ifiadicionalmente el Tribunal americano ha requerido que los poderes públicos demostrasen un interés apremiante de "orden más elevado" que justificase la inhibición o interferencia en la conducta religiosa de un individuo a través de una norma de aplicabilidad general. Aun en ese caso, los poderes públicos debían demostrar la inexistencia de otros medios menos gravosos para con la conducta religiosa que fuesen susceptibles de alcanzar y satisfacer el interés público. Sin embargo, una decisión tomada en 1990 por el Tribunal Supremo frenó la aplicación del citado test en el conocido caso

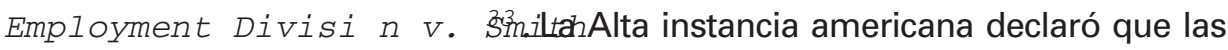

31 (1975) IR 81. En este caso se examinaba la constitucionalidad del artículo 12 de The Adoption Acde 1952, que preveía que «El solicitante o solicitantes debían pertenecer a la misma religión que el niño y que sus padres biológicos; en caso de que el niño fuese ilegítimo, los padres adoptivos debían tener el mismo credo que la madre". Esto tenía como consecuencia, evidentemente, que no eran permitidas las adopciones a matrimonios en los que el padre y la madre tuviesen creencias religiosas distintas. La inconstitucionalidad de esta previsión normativa fue declarada en virtud de lo dispuesto por el artículo $44.2 .3^{\circ}$ de la Norma Suprema. Y la posterior norma reguladora de la adopción, The Adoption Acđe 1974, en su artículo 4, excluyó el criterio de la religión de los padres adoptivos como requisito imprescindible para conceder la adopción.

32 El Test fue introducido en 1963 por el caso Sherbert v. Vern3314, US 398 (1963).

${ }^{33}$ Employment Divisi n v. Sm494 U.S 872 (1990). En el caso concreto, se denegó a los dos demandantes - miembros de la Iglesia Nativa Americana- la concesión de la correspondiente compensación económica por despido pues, de conformidad con los postulados de su religión, habían ingerido peyote (una droga alucinógena) en el ámbito laboral. La Corte Suprema americana dictaminó que la cláusula de libre ejercicio no puede exceptuar a nadie del cumplimiento de las leyes sobre drogas dado que las mismas no fueron aprobadas con finalidad religiosa alguna y son de aplicación universal. 
autoridades públicas autoras de la medida restrictiva ya no debían demostrar la existencia de un interés apremiante que cumplir, presumiendo la satisfacción del libre ejercicio siempre que dicha medida fuese neutral y de aplicación general, a menos que se tratase de una norma dirigida específicamente a una práctica religiosa o que infringiese un derecho constitucional adicional, como es en su caso la libertad de expresión. Ello suponía que la adopción de una normativa de carácter general por parte de los poderes públicos excluía la posibilidad de que un particular invocase la cláusula de libre ejercicio de la Primera Enmienda norteamericana, aun cuando aquélla interfiriese en una práctica religiosa determinada. Por contra, con la aprobación de la Ley de Restauración de la Libertad Religiosa en noviembre de 1993, se restableció la exigencia de la prueba del interés apremiante por parte de los poderes públicos, garantizando su aplicación en todos los casos donde el ejercicio religioso se viese recortado sustancialmente. Este hito legislativo trataba de dar satisfacción a dos objetivos básicos: impedir que los poderes públicos limitasen la libertad religiosa aun cuando tal restricción derivase de la aplicación de una norma general, excepto en el caso de que concurriese una fundada razón social, y que fuese indiscutible que la medida adoptada resultaba ser el medio menos restrictivo para la libertad religiosa.

Pero, cuatro años después del citado pronunciamiento, la Ley de Restauración de la Libertad Religiosa fue declarada inconstitucional en el caso City of Boerne, Texas V. Fpor Corte Suprema americana, la cual sostuvo que la regulación establecida por la citada Ley suponía una excesiva protección de la libertad religiosa, que implicaba una vulneración de los principios constitucionales ${ }^{34}$. Asimismo, fueron calificadas de excesivas las pruebas que el gobierno debía aportar para poder regular la libertad religiosa, pues dicha rigidez mermaba además la capacidad de la autoridad estatal para velar por la salud y el bienestar de los ciudadanos ${ }^{35}$.

La jurisprudencia irlandesa no ha previsto un haz de criterios seme-

${ }^{34}$ La Corte afirmó: «Legislation which alters the meaning of the Free Exercise Clause cannot be said to be enforcing the Clause»: 117 S.Ct. 2157, 2164 (1997).Véase una mayor exposición de esta Sentencia en John WITTE JR., Religion and the American Constitutional Experiment, Essential Rights andNestom,iGolorado, 2000, p. 124.

35 Con posterioridad a la declaración de inconstitucionalidad de la Ley de Restauración de la Libertad Religiosa, se ha aprobado una Ley sobre Uso religioso del Suelo y sobre las Personas dependientes de las Instituciones, que impide al gobierno interferir en el uso religioso del suelo y garantiza la libertad religiosa de los internos en las 
jantes al compelling temorteamericano que permita discernir la validez o invalidez constitucional de una norma atentatoria del libre ejercicio de la religión, a excepción del conocido "juicio de necesidad». La atención al criterio de necesidad implica que el Estado no puede imponer limitación alguna o discriminación entre personas pertenecientes a una confesión religiosa o entre ellas y las que no pertenecen a ninguna, salvo que dicho tratamiento desigual sea necesario para asegurar el libre ejercicio de la libertad religiosa y de conciencia. Esta limitación, sin embargo, afecta exclusivamente al Estado y no a personas o instituciones privadas. En McGrath and O?Ruairc V Trustees Maynooth Colibeglos demandantes habían sido contratados en su calidad de sacerdotes como profesores de un seminario que, a su vez, funcionaba como Universidad Pontificia pero, al abandonar su condición eclesiástica, fueron despedidos. Los afectados alegaron que el despido era constitutivo de discriminación por razón de su estatus religioso pero la Corte Suprema, unánimemente, rechazó tal pretensión al declarar que la prohibición del artículo $44.2 .3^{\circ}$ es aplicable exclusivamente al Estado y no a otras personas o instituciones de carácter privado, cuya política de selección del personal no se ve afectada por el principio de no discriminación constitucional. Es más, el hecho de que el colegio recibiese financiación estatal no alteró la entidad de dicha aseveración del Alto Tribunal respaldada, según su pronunciamiento, por un deber de abstención del Estado y de no interferencia en las cuestiones internas de una confesión religiosa concreta. El principio de autonomía organizativa de las confesiones religiosas previsto por el párrafo $5^{\circ}$ del artículo 44.2 de la Constitución irlandesa legitima a éstas, según la jurisprudencia de la Corte Suprema, para exigir una determinada conducta ética a sus empleados y las habilita para despedirlos en caso de su incumplimiento. Asimismo, el derecho de salvaguardia de la identidad religiosa y del carácter propio de las confesiones religiosas las habilita y les confiere plena autonomía para despedir a aquellas personas por ellas contratadas cuyo comportamiento choque frontalmente con el "ethos" de la institución para la que trabajan, quedando de este modo las confesiones religiosas eximidas de la aplicación de las normas generales sobre igualdad en el ámbito laboral ${ }^{37}$.

La aceptación de tal principio jurisprudencial no es categórica-

\footnotetext{
36 (1979) ILRM 166.

${ }^{37}$ The Employment Equality 1977 , The Unfair Dimissals 4977 y en la
} 
mente pacífica en la medida en que el Estado, una vez más, se ve indirectamente implicado en el respaldo de medidas atentatorias del principio de no discriminación, al financiar públicamente instituciones u organismos que establecen criterios selectivos de personal. Como se ha expuesto, esta cuestión es especialmente conflictiva con respecto a los hospitales y escuelas que reciben subvenciones públicas y que aplican criterios discriminatorios en sus políticas de admisión y selección de empleados. Además, no es sólo el principio de no discriminación el que resulta quebrantado, sino que dichas prácticas entran en contradicción, como se vio con anterioridad, con el principio de no financiación de la religión. Si bien la Corte Suprema estadounidense $-y$ siguiendo con el breve recorrido por la jurisprudencia norteamericana, que ha influido claramente en las decisiones de las Cortes irlandesas- ha considerado permisibles ciertas singularidades en cuanto a la aplicación de las normas sobre discriminación en el empleo, en orden a favorecer la acomodación de la cláusula de libre ejercicio - permitiendo su no imposición a las corporaciones religiosas en el momento de contratar a personal-, esta distinción sólo sería válida cuando se tratara de contratar a una persona de la religión concreta con el único objetivo de realizar tareas directamente relacionadas con las actividades de la misma. Sin embargo, las consecuencias de la Sentencia de la instancia irlandesa no son las mismas: el mantenimiento del orden de valores y del carácter o ideario propio de una escuela o centro hospitalario no debería justificar la adopción de políticas de preferencia en la contratación de personal afín a las creencias de las órdenes religiosas que lo regentan, más cuando dichas instituciones están financiadas en gran medida por fondos públicos ya que, de esta forma, el principio de no discriminación y el de no financiación se ven indirectamente vulnerados por el Estado ${ }^{38}$.

\section{El principio de autonomía de las confesiones religiosas.}

Recuérdese que el artículo $44.2 .5^{\circ}$ de la Constitución irlandesa dispone lo siguiente:

«Toda confesión religiosa tendrá derecho a administrar sus propios asuntos, poseer, adquirir y administrar bienes muebles e inmuebles y mantener instituciones con fines religiosos o benéficos".

$38 \mathrm{EI}$ "Group for Constitutional Review» ha puesto de manifiesto esta realidad. Op. Cit. p. 382. 
El significado de dicha previsión fue considerado por la Corte Suprema en el ya citado caso McGrath and O?Ruairc V. Trustees of Maynooth Colleg ${ }^{3} \varepsilon$, donde el principio de no discriminación entró en contradicción con el principio de autonomía de las confesiones religiosas. En el presente supuesto volvió a plantearse la polémica intervención del Estado como agente sustentador de instituciones dirigidas por órdenes religiosas cuyas líneas doctrinales y políticas de contratación y despido de personal resultan, en muchos casos, contrarias al principio de equidad y no discriminación constitucionalmente exigido. Si bien es cierto que, de conformidad con lo dispuesto por el Alto Tribunal irlandés, el principio constitucional de no discriminación vincula exclusivamente a los poderes públicos, ello no es óbice para afirmar que su participación en la financiación de organismos confesionales convierte al propio Estado en paladín de las prácticas discriminatorias de organismos privados, realidad difícilmente armonizable con el mandato constitucional reconocido en el artículo $44.2 .3^{\circ}$. Sin embargo, la Suprema Corte rechazó este argumento priorizando la independencia de las distintas iglesias para administrar sus propios asuntos y disponer sus propias normas de conducta en el seno de las instituciones por ellas gestionadas $^{40}$. El Alto Tribunal identificó, así, el derecho de autonomía interna de las confesiones religiosas con la imposibilidad para el Estado de coaccionar o inmiscuirse en ese campo, que se conceptúa como estrictamente privado y que, además, convierte en ilegítima cualquier intromisión de los poderes públicos en los asuntos internos de las distintas iglesias, ya que lo contrario implicaría una intromisión estatal en la libertad e independencia concedida constitucionalmente a toda organización religiosa.

El encuadramiento jurisprudencial dado al párrafo $5^{\circ}$ del artículo 44.2

39 (1979) I. L. M.R. 166. Como se ha visto, en este caso la Corte Suprema antepuso el principio de autonomía de las iglesias al propio derecho individual de no ser discriminado por motivos religiosos. La misma Corte ya había afirmado en un caso anterior -Mulloy v. Minister for Edu $\$ 2975 \mathrm{~d}$ dR, 88-que el párrafo $3^{\circ}$ del artículo 44.2 debe ser interpretado en conjunción con el párrafo $5^{\circ}$ del mismo artículo, de acuerdo con el criterio de interpretación sistemática. Más recientemente, la Alta instancia irlandesa ha corroborado dicho pronunciamiento en el caso Campaign to Separate Church and State $v$. The Minister for Education.

40 La Corte Suprema ha afirmado en el Caso Re Article 26 and the Employment Equality A1997) 2 IR 321 a 354, que cada confesión religiosa tiene derecho a definir su propia doctrina, sus normas de culto y sus respectivas normas de ordenación, pudiendo mantener y dirigir, en consecuencia, instituciones destinadas a propósitos religiosos o benéficos -instituciones educativas o médicas- de manera acorde con sus propias normas.

El término "confesión" ha sido definido como un vocablo genérico en el que cabe incluir las distintas iglesias, sociedades religiosas o congregaciones bajo cualquier nom- 
ha tenido su plasmación en la legislación reguladora de la prohibición de discriminación en el ámbito laboral. Así, la interpretación dada por la Corte Suprema al citado precepto ha sugerido la redacción de la sección 37(1) de la Employment Equality Ade 1998. La citada ley prohíbe con carácter general la discriminación por motivos religiosos en el ámbito laboral, sin embargo, contiene una excepción a dicha norma general que será aplicable cuando la entidad contratante sea una confesión religiosa. De esta forma, la prescripción legislativa impide al órgano contratante que rehúse contratar, despida o rechace la promoción de ninguna persona sobre la base de motivaciones religiosas, pero la sección 37 (1) admite una salvedad a dicha regla general. Ésta establece:

«37.- (1). Una institución religiosa, educativa o médica que se encuentra bajo la dirección o control de un organismo creado para satisfacer fines religiosos o entre cuyos objetivos se encuentre la provisión de ciertos servicios en un contexto que promueve ciertos valores religiosos no estará afectada por la prohibición de discriminación alguna entre las personas por motivos religiosos si:

(a) da un tratamiento más favorable, debido a motivos religiosos, a un empleado o a un presumible empleado sobre otra persona, si ello es necesario para mantener el orden de valores de la institución, o

(b) adopta una acción que es razonablemente necesaria para evitar que un empleado o presumible empleado pueda afectar al orden de valores de la institución».

La redacción del citado enunciado normativo permite deducir la facultad de que disponen las confesiones religiosas para incluir entre sus normas internas cláusulas de salvaguardia de su identidad religiosa y carácter propio, que quedan exentas del ámbito de aplicación de la legislación general en materia antidiscriminatoria.

Una vez más, de manera evidente, se pone en entredicho la neutralidad del Estado frente al factor religioso ya que, si bien -tal y como ha quedado expuesto en epígrafes anteriores- la Constitución irlandesa realiza una apreciación positiva del hecho religioso, dicha valoración no lleva aparejado un deber de los poderes públicos de impulso y sustentación eco-

${ }^{41}$ Corrobora estas opiniones CASEY. El autor argumenta que la interpretación dada al artículo $44.2 .5^{\circ}$ parece legitimar a las confesiones religiosas para utilizar dinero público con el fin de financiar políticas que si fuesen adoptadas por el Estado mismo vulnerarían el principio de no discriminación del artículo 44.2.3 ${ }^{\circ}$, situación que califica de "kafkiana». En estos términos, el autor se plantea si tiene cabida constitucional la adopción por parte de las confesiones religiosas de políticas discriminatorias en materia de contratación del personal docente en las escuelas por ellas gestionadas, concluyendo que estas prácticas no pueden quedar amparadas por el derecho de las distintas confesiones a dirigir sus propios asuntos. Véase la opinión del autor en Constitutional Law in I lopl \&itapp. 571-572. 
nómica de las entidades religiosas hasta extremos que contradigan el propio espíritu del derecho de libertad religiosa 41 .

5. Cuando el principio de autonomía de las confesiones o grupos religiosos colisiona con la protección de la libertad religiosa individual, con el principio de no discriminación religiosa y con la prohibición de financiación estatal de la religión: El caso de las escuelas.

El párrafo $4^{\circ}$ del artículo 44.2 prevé:

2.4. "La legislación de ayuda estatal a las escuelas no discriminará entre las escuelas dirigidas por diferentes confesiones religiosas, ni deberá crear obstáculos al derecho de cualquier niño a asistir a una escuela subvencionada, sin tener que asistir a la instrucción religiosa en dicha escuela».

Como es sabido, en estrecha relación con la libertad de enseñanza se encuentra la cuestión relativa a la financiación estatal de los centros educativos privados. En la Norma Suprema irlandesa, el lenguaje de la norma constitucional es en esta ocasión prescriptivo y su interpretación literal permite deducir que existe un deber de financiación pública de los centros docentes privados confesionales. Sin embargo, no cabe dejar de lado que dicho deber de subvención pública no puede comprenderse plenamente si se prescinde de una remisión insoslayable al apartado 3 del artículo 42, relativo al derecho a la educación, que prevé lo siguiente:

«El Estado proporcionará una educación primaria gratuita y se esforzará en suplir y dar ayuda razonable a la iniciativa privada y a la iniciativa de grupos en materia de educación y, cuando lo requiera el bien público, proporcionará otros medios de instrucción, respetando en todo caso el derecho de los padres, especialmente en materia de formación religiosa y moral».

De este modo, el deber de subvención de la educación confesional impuesto a los poderes públicos por la Norma Suprema en el artículo 44.2.4 ${ }^{\circ}$ instituye una excepción al principio de no financiación estatal de la religión, excepción que encuentra su justificación en el propio Texto fundamental a partir del deber que éste deposita sobre el Estado de hacer efectivo un extenso derecho a la libertad de enseñanza, constitucionalmente concebido como proyección instrumental de los derechos educativos paternos. Es evidente que el papel subsidiario que la Constitución otorga al Estado en materia educativa, como lógica consecuencia del carácter prioritario que ésta atribuye a los derechos educativos de los padres, ha servido de argumento paliativo para aceptar la constitucionalidad de un sistema de financiación pública de escuelas de primaria y secundaria, en su gran mayoría confesionales.

En este momento debe incidirse en que todas las cuestiones aquí planteadas derivan de un compromiso histórico adquirido por el Estado 
irlandés con las confesiones religiosas $-\mathrm{y}$ en especial con la Iglesia Católica- en materia educativa, en virtud del cual el poder y control confesional sobre la gestión de las escuelas ha ido consolidándose en Irlanda desde el siglo XIX. El papel subsidiario atribuido por la Norma Suprema al Estado en el ámbito de la educación contrasta con lo previsto por la mayor parte de las Constituciones europeas, que configuran el derecho a la educación como un derecho social de prestación directamente exigible de los poderes públicos. La mayor parte de las Normas constitucionales europeas atribuyen al Estado el deber de crear centros escolares públicos que hagan efectivo dicho derecho subjetivo; sin embargo, en el caso de Irlanda, una concepción subsidiaria del papel del Estado en materia educativa conduce a que la enseñanza pública sólo se establezca allí donde la enseñanza privada no cubra las necesidades educativas. De esta forma, Irlanda representa la concepción más amplia y radical de la libertad de enseñanza en la medida en que su texto constitucional supedita la enseñanza pública a las carencias que se deriven de la implantación de una enseñanza privada, que de factes estrictamente confesional.

Sin embargo, varias cuestiones dificultan la conciliación del papel asumido por el Estado como agente sustentador de la iniciativa educativa privada con los principios constitucionales de no discriminación religiosa y de no financiación de la religión: en primer lugar, la pública financiación de los ministros de la religión católica en las escuelas que se encuentran bajo control y gestión de órdenes pertenecientes a dicha confesión; y, en segundo lugar, la pública financiación del llamado "Currículo Integrado" vigente hasta el año 1999.

El primero de los asuntos apuntados -relativo a la constitucionalidad de la retribución de los salarios de los capellanes que prestan sus servicios en centros gestionados por órdenes religiosas católicas a través de fondos públicos- fue planteado y examinado por la Corte Suprema irlandesa en el caso The Campaign to Separate Church and State Ltd V. The Minister for Educat'i declarando la constitucionalidad de la controvertida cuestión. Mediante la interpretación sistemática de los artículos 44.2.4 ${ }^{\circ}$ y 42.3 de la Constitución, la Alta Instancia irlandesa consideró que el Estado está legitimado para financiar las escuelas de las diferentes confesiones religiosas y que éstas pueden incluir la instrucción religiosa como parte integrante de su currículo — debiendo considerarse incluidos en el concepto de "formación religiosa" la oración y el desarrollo espiritual de los menores, para garantizar su formación integral en dicho ámbito-. La

42 (1998) 2 ILRM. 81. 
Corte dispuso, asimismo, que el tenor del artículo $44.2 .2^{\circ}$ proscribe la financiación directa por el Estado de una determinada religión pero, en ningún caso, el soporte público de un sistema educativo confesional tradicionalmente vigente en Irlanda y cuyo sustento estatal se encuentra expresamente previsto y protegido por la Constitución. De manera que, el pago de los salarios de los capellanes en las escuelas comunitarias por parte del Estado no puede concebirse como una efectiva financiación de la religión en los términos prohibidos por el artículo 44.2.2 ${ }^{\circ 43}$.

La segunda de las cuestiones apuntadas engarza directamente con el derecho de las confesiones religiosas a crear centros docentes y a mantener y promocionar en ellos su propia doctrina como base orientadora de la función educativa. En Irlanda, al igual que en el resto de países europeos, las confesiones religiosas -en el ejercicio de su derecho de autonomía y en concordancia con los derechos educativos de los padres- pueden establecer y dirigir centros docentes en todos los niveles educativos. Dicha libertad se concreta en las facultades de selección del profesorado, admisión de alumnos y, en particular, en el libre establecimiento de sus normas de régimen interno, actuando como límite en todo caso la libertad de conciencia de los alumnos, libertad que cristaliza en el respeto de la voluntad de éstos frente a la recepción de la instrucción religiosa. Este derecho de los alumnos —conceptuado como derecho constitucional de primer orden- alcanza una especial importancia y significación en un país como Irlanda, donde la casi totalidad de los centros de enseñanza primaria y secundaria son escuelas establecidas bajo patrocinio diocesano, que reciben financiación estatal y respecto de las cuales el Estado reconoce explícitamente su carácter confesional. Sin embargo, la ausencia de legislación específica en la materia y la imposición fáctica de un sistema confesional de educación han conducido a que la efectividad de dicha garantía consti-

\footnotetext{
${ }^{43}$ Gerard WHITE reconoce que el Estado debe proporcionar servicios educacionales y debe prestar especial soporte a los derechos de los padres a este respecto, con especial atención a la formación religiosa y moral de sus hijos. Sin embargo, discrepa con la interpretación dada por la Corte Suprema al artículo 42.4 de la Constitución, pues considera que este precepto no ampara una financiación estatal de los capellanes en las escuelas pertenecientes a la confesión católica, ya que una interpretación del precepto en estos términos no puede armonizarse con la prohibición prevista en el artículo 44.2.2 — prohibición estatal de financiación de la religión_ - de la misma Norma Suprema, cuya imperatividad queda así diluida. Véase la opinión del autor en "Religion and the Irish Constitution", op. cit., p. 735.

${ }^{44}$ Es importante destacar que hasta la aprobación de la Education Acck 1998 no ha existido una legislación que haya regido el sistema educativo irlandés. Éste ha sido tradicionalmente administrado por normas sin carácter legislativo o circulares del Ministerio de Educación.
} 
tucional haya quedado diluida en la letra de previsiones reguladoras del sistema nacional de escuelas, carentes de valor estatutario ${ }^{44}$.

Como ha quedado expuesto, la cobertura legislativa y jurisprudencial otorgada al principio de autonomía de las confesiones religiosas ha justificado la no adopción de medidas tendentes a garantizar el principio de no discriminación en todas aquellas instituciones que se encuentran bajo control confesional. Las escuelas no son una excepción, sino más bien el ámbito donde las iglesias, y especialmente la Iglesia Católica, han obtenido un mayor respaldo estatal en su propósito de salvaguardar el orden de valores que les es propio. La Iglesia católica preserva - y ha preservado durante los años transcurridos tras la aprobación de la Norma Suprema- el derecho a mantener la presencia de su doctrina en las instituciones por ella dirigidas.

Así, con la aprobación en 1971 del Ilamado "Currículo Integrado" para las escuelas de Educación Primaria por el Departamento de Educación, se estableció que la formación religiosa debía impregnar la totalidad del programa educativo en las escuelas primarias, sin erigir disociación alguna entre la instrucción religiosa y el resto de materias educativas $^{45}$. La vigencia de la citada previsión - que nunca estuvo recogida en un documento legislativo, sino sólo en el Manual de Profesorado de Educación Secundaria- ha pervivido hasta tiempos muy recientes, a pesar de que su validez constitucional ha sido cuestionada en varias ocasiones por la doctrina y por diversos grupos sociales ${ }^{46}$.

La vigencia del Ilamado "Currículo Integrado" ha planteado serios problemas, en la medida en que su implementación vulneraba varios derechos subjetivos concurrentes, dotados todos ellos de cobertura constitucional. En primer lugar, y de manera más evidente, resultaba quebrantado el derecho a la libertad de conciencia de todos aquellos

\footnotetext{
45 Primary School Curriculum, Teacher?s Han(d)

${ }^{46}$ En 1991, la Asociación Ilamada "Campaña para la Separación entre la Iglesia y el Estado" (Campaign to Separate Church and State), que ya había planteado la inconstitucionalidad de la financiación pública de los ministros de educación católica en las escuelas, inició un proceso a favor de la declaración de inconstitucionalidad del llamado "integrated curricul on el fin de conseguir que la instrucción religiosa en las escuelas primarias financiadas por el Estado fuera una materia independiente y separada del resto. Sin embargo, a la vista de las promesas gubernamentales sobre la reforma de este asunto en el "Papel Blanco sobre Educación», el caso fue abandonado. Véase al respecto WALSH, "Legal Challenge to integration of Religious Studies", Irish Times, 17 de septiembre de 1991, p. 1.
} 
alumnos que podían verse constreñidos a recibir una educación teñida de rasgos confesionales, contraria a sus convicciones ${ }^{47}$. $Y$ en segundo lugar, la citada previsión educativa vulneraba asimismo el derecho de los padres a elegir para sus hijos la educación que más se adecue a sus convicciones religiosas o morales. Así, si se parte de que el artículo 42 de la Norma Suprema reconoce a la familia como el educador primario y natural del niño y establece la obligación del Estado de adoptar las previsiones necesarias para hacer efectiva la voluntad de los padres en esta materia, se llega a la conclusión de que una medida de las características descritas lesiona la vigencia del propio derecho de aquellos padres que se decantan por una opción irreligiosa o antirreligiosa para sus hijos, o simplemente el derecho de aquellos padres que profesan unas creencias religiosas distintas a la religión católica ${ }^{48}$.

Por consiguiente, la implementación de una medida educativa que impide el ejercicio del derecho de libertad de conciencia por sus titulares no puede ser aceptada desde ninguna de las dos perspectivas expuestas, ni a partir de un reconocimiento del derecho de los niños a ausentarse de la instrucción religiosa en las escuelas financiadas públicamente, ni sobre la base del derecho de los padres a elegir la formación moral o religiosa de sus hijos. Aun así, la situación se agrava cuando

48 Véase Gerard WHYTE: «Education and the Constitution» en AAVV: Religion, Education and the Constitu1992, pp. 107-108. Ha sido igualmente sugerido que el "Integrated Curriculum» es contrario al derecho de libertad de pensamiento, conciencia y religión previsto en el artículo 9 del Convenio Europeo de Derechos Humanos, véase al respecto CLARKE: "Freedom of Thought and Educational Rights in the European Convention", Ir. Ji28, 1987.

Asimismo, la vulneración de derechos constitucionales derivada de la implementación de dicha política educativa ha sido puesta en evidencia por David ALVEY: Irish Education: The Case for Secular Refofthurch and State Books, Dublín, 1991, Capítulos 1 y 2, pp. 10-42.

49 El Informe del Constitutional Review Grourecomendó la supresión del "Integrated Currículum" debido a los conflictos constitucionales que este creaba entre el derecho de todo niño a no ser constreñido a recibir formación religiosa en una escuela financiada públicamente y el derecho de las escuelas confesionales que reciben esta financiación a proporcionar una educación enteramente confesional. Report of the Constitutional Review Gropp cit., pp. 386-387. Por su parte, Desmond M. CLARKE ha sostenido importantes objeciones ideológicas al sistema educativo vigente debido a su carácter cuas ienteramente confesional. El autor mantiene que un sistema en el que las escuelas confesionales tienen el monopolio en la educación es inconstitucional. Su postura no se dirige per sen contra de las escuelas religiosas sino contra su monopolio en la educación. Dado que en la mayor parte del país sólo existen escuelas confe- 
dicha capacidad de elección ya ha sido previamente condicionada por la práctica inexistencia de centros educativos distintos a los confesionales católicos ${ }^{49}$.

En 1999, ante el descontento de distintos sectores de la sociedad y ante las voces que defendían su posible inconstitucionalidad, fue aprobado el Nuevo Currículo para la educación primaria. Éste fue introducido en las escuelas nacionales - reconocidas y financiadas por el Estadoen septiembre de 1999. La disociación de horarios entre la instrucción religiosa y las demás materias garantiza su adecuación a la nueva ley sobre educación, la Education Acde 1998, que recoge expresamente la prohibición constitucional de obligar a ningún estudiante a acudir a clases sobre cualquier materia que sea contraria a las creencias de sus padres. Sin embargo, si bien el Nuevo Currículo es promulgado por el Ministerio de Educación, se otorga asimismo un amplio campo de actuación a cada escuela particular para que, en su desarrollo e implementación, adecue el Currículo a los principios que rigen su propio orden de valores $^{50}$. Entre los contenido fijados por el Ministerio se encuentra el Área "Social, Personal and Health Educaestableciéndose expresamente que dicha área de conocimiento tiene una evidente dimensión moral y ética que ha de ser desarrollada en el marco del orden de valores y del carácter propio de cada escuela ${ }^{51}$. Se sigue otorgando, por tanto, un amplísimo grado de autonomía a las escuelas para adaptar los contenidos del Currículo a su propio ideario.

sionales, el autor afirma que los derechos de los niños y de los padres no creyentes o de aquellos que desaprueban las escuelas de las iglesias, están siendo obstruidos debido a la colisión entre Estado e Iglesia en la política educativa. Asimismo, apunta que la característica fundamental de un ordenamiento legislativo plural es que los derechos de las minorías estén protegidos en igual grado que los derechos de las mayorías. Además asevera que el único principio consistente y explícito de la Constitución es aquel que establece que el Estado debe mantenerse estrictamente neutral en materia de creencias religiosas. Véase la opinión del autor en Church and Sta,tGork University Press, 1984, pp. 219-226.

50 Documento del «National Council for Curriculum and Assessment».

${ }^{51}$ Expresamente se contiene en el documento que «El término Currículo hace referencia al contenido, estructura y procesos de enseñanza y aprendizaje que imparte la escuela en concordancia con sus propios objetivos educativos y con sus propios valores. Éste incluye elementos explícitos e implícitos. Entre los primeros se encuentran todos aquellos conceptos, técnicas, áreas de conocimiento y aptitudes que los niños aprenden en la escuela como parte de su desarrollo personal y social. Los elementos implícitos son aquellos factores que constituyen el orden de valores y el espíritu gene- 
En relación con ello, debe señalarse que la nueva Equal status Act de 2000, establece en su artículo 7 una excepción al principio de no discriminación en el ámbito educativo cuando se trata de escuelas que defienden un ideario religioso propio. Así, dichas instituciones podrán dar preferencia, en su política de admisión de alumnos, a aquéllos que pertenezcan al credo propio del centro e, incluso, están legitimadas para denegar el ingreso a estudiantes cuyas creencias diverjan de los valores religiosos que aquéllas tratan de difundir, siempre que se demuestre que dicho rechazo es "esencial" para mantener su ideario u orden de valores $^{52}$. Es evidente, una vez más, que el legislador irlandés otorga —-también en el ámbito educativo- una indudable prevalencia al derecho de autonomía de las iglesias frente al resto de derechos constitucionales previstos por el artículo 44 de la Constitución y, especialmente, frente al principio de no discriminación religiosa. Se establece para ello una «cláusula de esencialidad" cuya indeterminación puede justificar actuaciones "esencialmente discriminatorias", sobre la base de las creencias religiosas tanto de alumnos como de docentes.

La tesis defendida para legitimar los principios sobre los que se asienta el sistema de enseñanza irlandés vigente, radica en el respeto que éste otorga al derecho de los padres de elegir para sus hijos una educación que se adecue a sus convicciones religiosas y morales, dado que dicha elección es mayoritariamente confesional y católica ${ }^{53}$. Sin embargo, la puesta en práctica por el Estado de un sistema educativo estrictamente

${ }^{52} \mathrm{Si}$ bien la Education Acte 1998 establece en su artículo 33 que el Ministerio de Educación debe encargarse de regular la política de admisión de alumnos en los centros educativos financiados públicamente, sin embargo dicha regulación es todavía inexistente. Asimismo, la Education (Welfare) dhec2000 dispone en su artículo 19 que "el principio de no discriminación en la admisión de alumnos encuentra su excepción en la política de acceso y despido de la escuela, que en todo caso, según dispone el artículo 15 de la Education Acte 1998, debe ser publicada».

${ }^{53} \mathrm{~A}$ este respecto resulta significativa la reserva que interpuso Irlanda al artículo 2 del Protocolo Adicional Número 1 del Convenio Europeo para la protección de los Derechos Humanos y de las Libertades Fundamentales de 1950. Éste dispone que "A nadie se le puede negar el derecho a la instrucción. El Estado, en el ejercicio de las funciones que asuma en el campo de la educación y de la enseñanza, respetará el derecho de los padres a asegurar esta educación y esta enseñanza conforme a sus convicciones religiosas y filosóficas». Irlanda sostuvo en dicha reserva que la regulación del derecho a la educación contenida en el Convenio no es lo suficientemente explícita en el reconocimiento y protección del derecho de los padres a proporcionar a sus hijos educación en sus propias casas o en escuelas de su elección, sean éstas escuelas privadas o establecidas o reconocidas por el Estado. 
favorecedor de la opción religiosa mayoritaria conlleva un categórico desconocimiento de los derechos de las minorías religiosas, entre las que se encuentran todos aquellos padres y menores que mantienen una postura agnóstica frente al fenómeno religioso y que no desean una educación confesional ${ }^{54}$.

\section{CONCLUSIONES: EL "ESTADO DE SALUD» DE LA LIBERTAD RELIGIOSA EN IRLANDA.}

La configuración constitucional de las facultades inherentes al derecho de libertad religiosa en la Norma Fundamental irlandesa de 1937 y la interpretación jurisprudencial de los preceptos constitucionales que las establecen han inspirado, a lo largo del período de vigencia de la Constitución y hasta la actualidad, la legislación y la actuación de los poderes públicos frente al hecho religioso. La doctrina de la subsidiariedad del Estado en el desarrollo de la educación de los menores frente al papel primordial de los padres, el valor prioritario otorgado al principio constitucional de autonomía de las confesiones religiosas, o el establecimiento de exenciones a la prohibición de financiación de la religión a favor de las instituciones religiosas dedicadas a fines no estrictamente religiosos, son instrumentos que han venido a respaldar la virtualidad práctica del «elemento cuantitativo" como parámetro para justificar un tratamiento favorecedor de la confesión religiosa de mayor relevancia sociológica.

Como ha quedado expuesto a lo largo de este estudio, la utilización por parte de la jurisprudencia de criterios hermenéuticos divergentes en la interpretación de los distintos mandatos contenidos en el artículo 44, ha favorecido que, con carácter general, la propia letra de la Constitución haya sido interpretada de la manera que más favorece a la autonomía e independencia de las iglesias frente a los demás derechos y principios contenidos en el precepto constitucional. Así, se ha otorgado a las confesiones

${ }^{54} \mathrm{Y}$ en esta minoría cabe incluir a los movimientos de padres que desde hace algunos años están abogando por la creación de escuelas multiconfesionales -las llamadas "educate togethex"en las que se garantiza una enseñanza globalmente "neutra" por medio del respeto de la libertad de conciencia de los alumnos; a los colectivos como Campain to separate church and stateereclaman que la religión salga de una vez por todas de las aulas para desarrollarse en plena libertad en el ámbito familiar o eclesial; o a todas aquellas personas, pertenecientes a religiones distintas de la mayoritaria, que ven vulnerados sus derechos constitucionales cuando se encuentran constreñidos a enviar a sus hijos a colegios con una determinada orientación ideológica. 
religiosas -en virtud de un deber de no interferencia pública en sus asuntos internos- un extraordinario poder de decisión, que les ha permitido adoptar y aplicar políticas de selección de personal difícilmente conciliables con los principios de igualdad y no discriminación. Sin embargo, lo cuestionable no es la misma potestad organizativa de la que el Texto constitucional ha dotado a las confesiones religiosas, sino el respaldo que dicha autonomía ha recibido mediante una interpretación extensiva del deber de no interferencia estatal en su seno, interpretación que ha justificado la inhibición de los poderes públicos frente a practicas desconocedoras del conjunto de derechos subjetivos reconocidos por el artículo 44. Deber de omisión que se ha transformado, a mayor abundamiento, en un deber de actuación positiva mediante el establecimiento de excepciones que justifican y exigen el soporte financiero de todas aquellas instituciones dependientes de órdenes religiosas que, por no tener un fin exclusivamente religioso, reciben la financiación del Estado, pero que, sin embargo, no renuncian a su propia autonomía para aplicar en ellas las prácticas que estimen convenientes en orden a mantener la vigencia de su doctrina.

Este deber de inhibición, transformado en obligación de financiación estatal de aquellas actividades no estrictamente religiosas desarrolladas por las iglesias, alcanza su punto álgido en el ámbito de la enseñanza. En este asunto, la interpretación jurisprudencial dada al artículo 44 de la Constitución se ve respaldada por lo previsto en el artículo 42 de la misma.

Los constituyentes irlandeses adoptaron una versión maximalistade la libertad de enseñanza, por la que — partiendo del presupuesto de que el Estado reconoce que la familia es el educador primario y natural del menor- los poderes públicos se comprometen a respetar el derecho y el deber que ostentan los padres para asumir —en la medida que lo permitan sus medios- la educación de sus hijos, especialmente en materia moral y religiosa.

Sin embargo, y si bien es cierto que la libertad de enseñanza prevista constitucionalmente exige, para garantizar su efectividad, un modelo de financiación pública de los centros docentes privados, esta exigencia no debería eximir al Estado de la adopción de un sistema de control de la gestión y funcionamiento de estos centros, en orden a procurar una adecuada protección de los derechos educativos y de conciencia de todos los integrantes de la sociedad irlandesa y no sólo de aquéllos que pertenecen a la confesión religiosa mayoritaria. 